\title{
Unpublished two stelae dating back to the Middle kingdom,
} CG.20751,CG. 20752

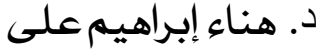

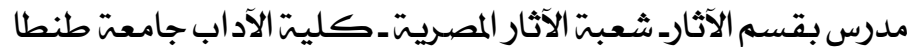

\begin{abstract}
:
This research is about two limestone stelae discovered in Abydos and they are kept in the Egyptian museum. In a good condition the first stelae is kept under the number 20752, and the second one is under the number 20751; and both of them are not displayed.

The objective of this research is to reach the identity of the owner of each stela and to read the offering texts engraved on them. Moreover, it compares them with other similar stelaes found in Thebes and Abydos to identify the characteristic features, the details and the emergence of this kind of stelas.

Key words: Offering table - stalea - IRR - Nakht- semicircular - Ritual text invocation formula- wsir - Anupis- wig

Main subject: Ancient civilization.

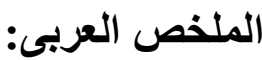

يتناول هذا البحث دراسة لوحتين من الحجر الجيرى عثر عليها في ابيدوس، ومحفوظتان بالمتحف المصري

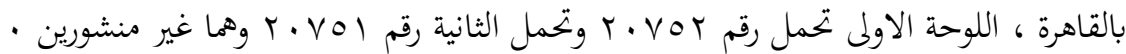

يهدف البحث تحديد هويه صاحب كل لوحة من اللوحتين وقراءة نصوص التقدمة المنقوشة عليهما ، فضلاً عن محاولة مقارنتهما بلوحات اخرى مماثلة من طيبة وابيدوس لتحديد سمات وتفاصيل ونشاة مثل هذا النوع

General من اللوحات . 1( description'
\end{abstract}
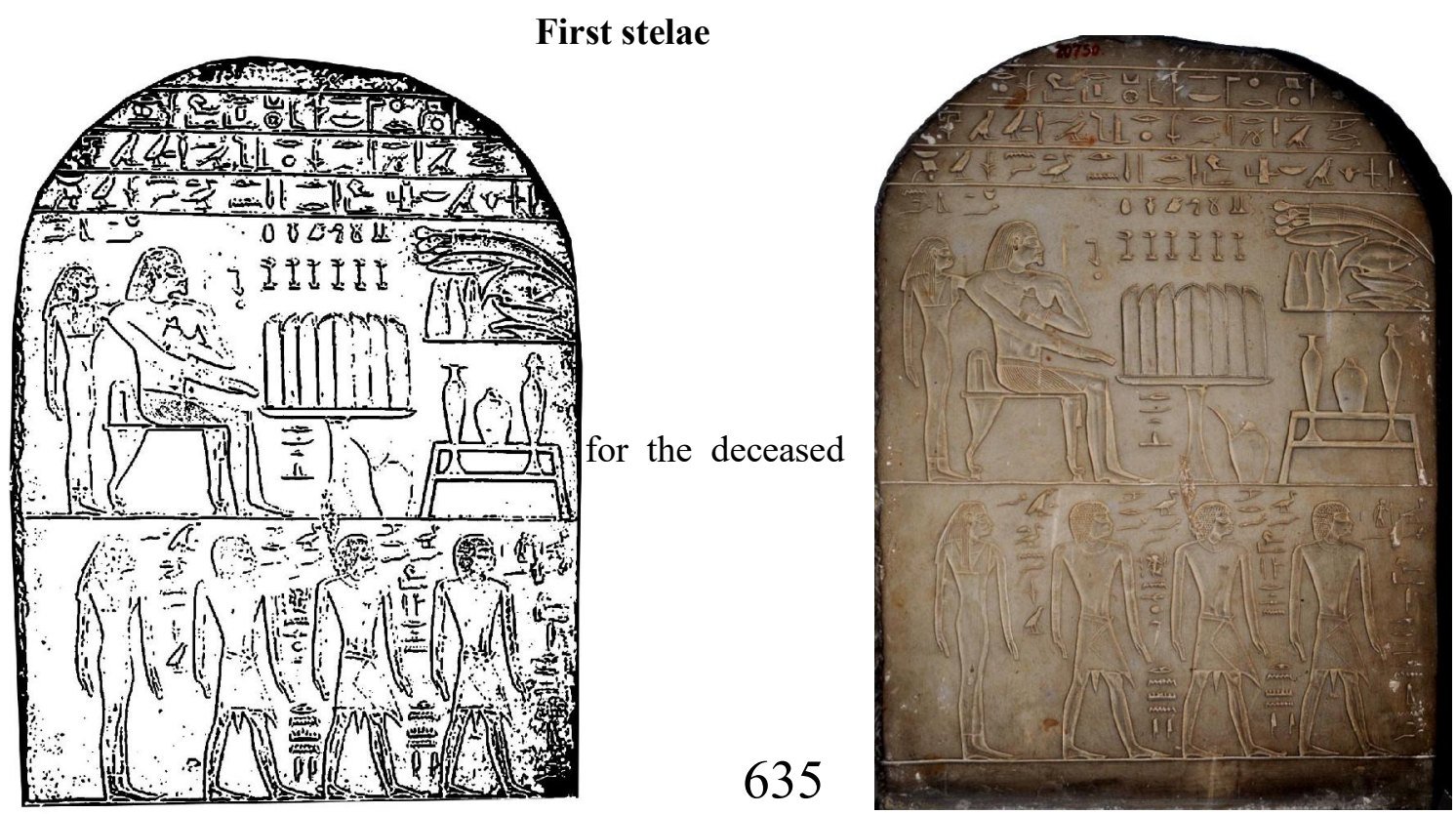
his family.

Place of discovery: called irr $\circlearrowright$ and North Abydos.

Present location: Egyptian museum under the numbers 20752

The material of the stelae : limestone.

\section{I- The lunette:}

Description of the stelae: the top of the stelae is semicircular in shape. The middle section of it contains the main scene of the Stelae. The lower section depicts the family of the deceased. The upper semicircular section contains a Hieroglyphic Text composed of three lines. The text is readable from right to left and it is stretched above the main scene which is representing the owner of the stelae.

First line is saying :

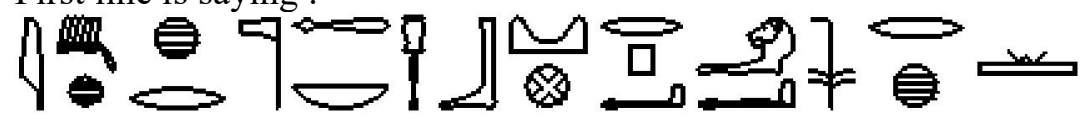

imAx xr nTr aA nb AbDw iry-pa(.t) HAty-a rx nsw

The one known to the great god lord of Abydos, the crown prince, the governor of the province, the one known to the king.

Second line is saying:

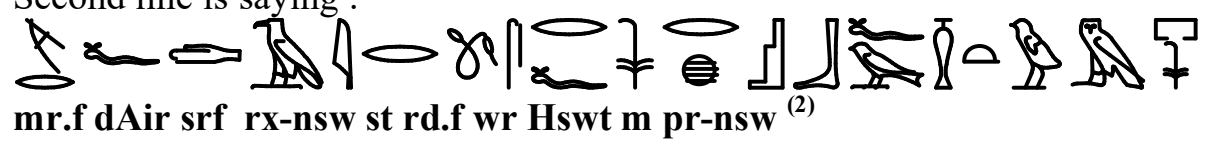

The beloved of the one controlling himself, whose position is known to the king, the praised one in the palace.

Third line is saying :

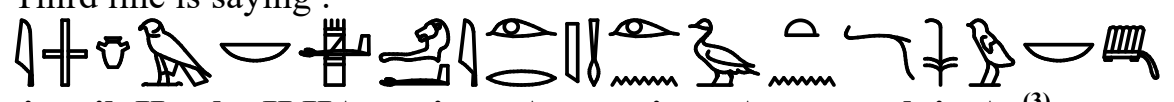

imy ib Hr nb aH HAty-a irr mAa-xrw ir $n$ sAt ns sw nb imAx ${ }^{(3)}$

The one in the heart of Horus, lord of the palace, governor of the province, IRR born of "sAt ns sw " lord of the venerable ones.

\section{II- The scenes:}

The middle section of the stelae has got a depiction of the deceased sitting down ${ }^{(4)}$ on a chair which has a back clearly seen and legs resembling the lion paws (the front paws are distinguished from the rear ones). The deceased is wearing a long curly hair wig and showing the ears from underneath. He is putting a collar around the neck. He is wearing a kilt. His left hand is holding a piece of fabric and putting the hand on his chest. Meanwhile, his right hand is outstretched on his thigh towards his knees. In front of him is an offering table. His wife is standing right behind him putting her left arm on his shoulder and her right hand is resting aside. She is wearing a long tight dress with two straps around the shoulders. The style of that dress was the most popular one at the time. She has got long hair resting on the shoulders and the back.

The posture of both the deceased and his spouse is resembling those of the statues dating back to the old kingdom, showing the ladies and the men sitting down. But the difference-seen in those of the old kingdom- is that the man was holding a stick, a bow or an arrow. 
Right above the representation of the spouse, there is a text saying :

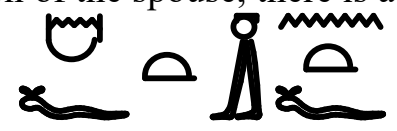

Hmt. F int .f ..... his wife" Intf "

The offering table is loaded with different supplies. It is occupying the whole space in the middle section. It is carried by eight ditch reeds, each four of them are opposite to the other. Above the offerings table (towards the direction of the deceased) there is a part of the offerings text formula saying:

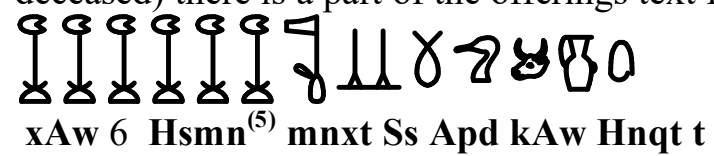

Six thousands of natron salt packets, cloth, alabaster ,birds, oxen, beer and bread loaves.

Below the right side of the offerings table there is an ewer-probably- containing sanitation water which is used after eating that food.

Below the left side of the offerings table there is a phrase which is saying: " $\mathbf{d b H t}-$

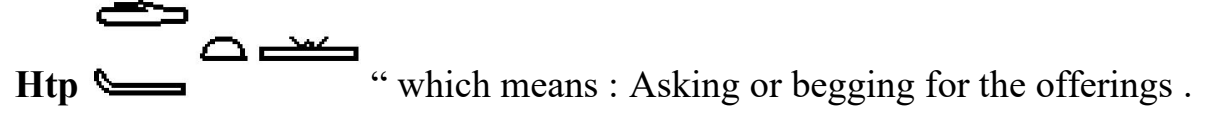

The right part underneath the offerings table has got a representation of a small stand which could carry the ewer, the pans and other pots. And above that stand there are representations of different kinds of food such as onion, fish and bread.

The third-and last-section of the stelae has got the depiction of the deceased's sons and his mother, as mentioned in the text.

The sons are wearing short curly hair wigs covering the ears. They are wearing kilts going above the knees, and from the middle of the kilt there is a strap which is hanging down. Each one of them is outstretching his arms aside and looking towards the outside of the Tomb. Meanwhile, they are followed by their grandmother (the deceased's mother) who is wearing a tight dress like the wife of the deceased and she is putting her arms aside as well.

Each figure of the sons and the mother is preceded by a text which is telling the identity of each one of them and his/ her name.

- the first son is preceded by the following text.

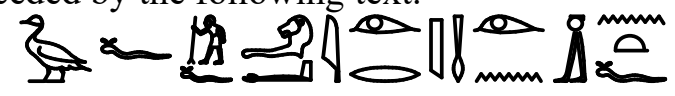

sA.f smsw.f HAty-a Irr mAa-xrw ir.n int.f

His son, his beloved, governor of the the province irr, the true of voice born of intf -The second son is preceded by the following text:

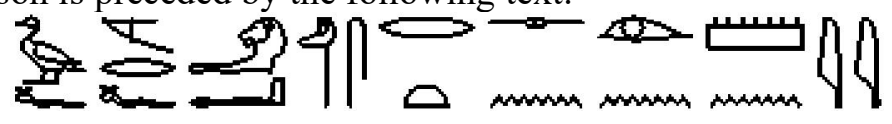

\section{sA.f mr.f HAty-a s-n-wsrt ir n Mny}

His son, his beloved, governor of the province senowsert born of Meny.

- The third son is preceded by the following text: 


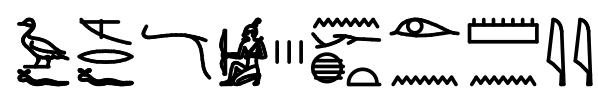

sA.f mr.f imy-r mSa nxt ir n Mny

His son, his beloved, the army leader "nAxt ," born of mny.

-The lady is preceded by the following text:

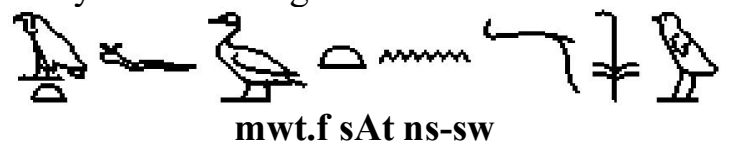

-It is noticed here from the text that:

His mother "sAt ns-sw".

1- The elder son has got the very same name of his father irr .

2- His elder son is from another wife called intf who is represented behind her husband as she was considered the principal wife. Meanwhile, the second and the third sons are from another secondary wife called meny ${ }^{(6)}$.

\section{Second stelae}
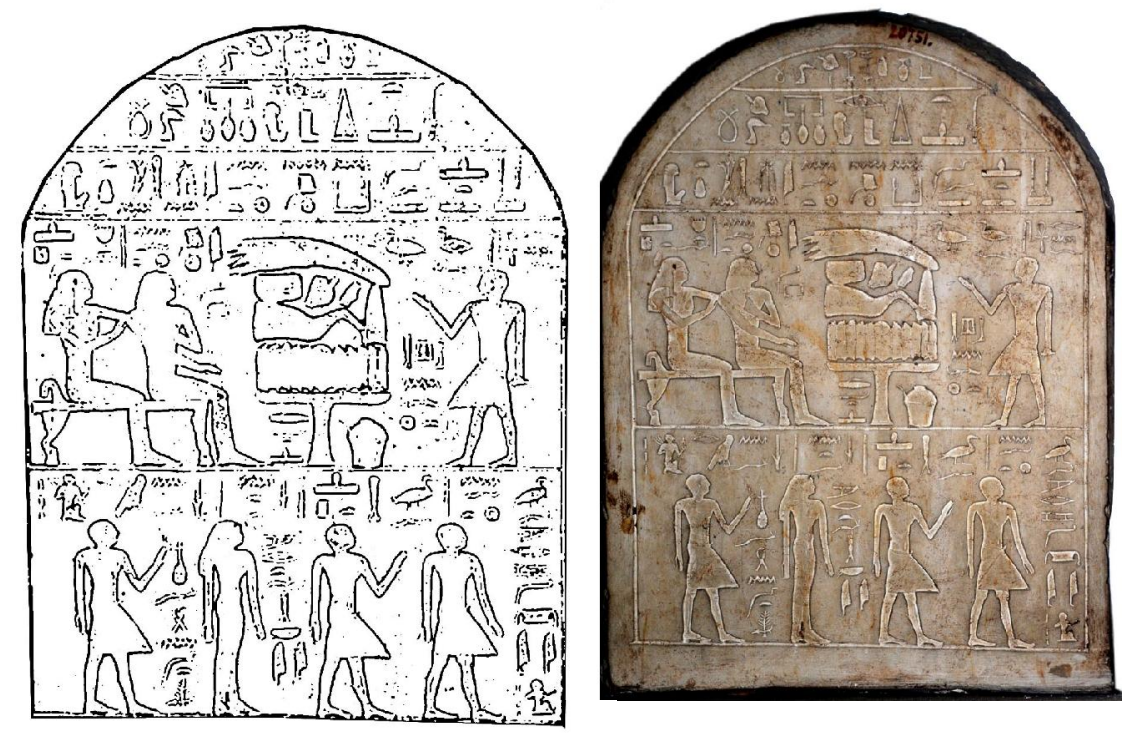

Subject: funeral stelae for the deceased called " nxt" 约 Place of discovery: North Abydos.

Present location: Egyptian museum in Cairo under the number 20751.

\section{I- The lunette:}

The top of the stelae is semicircular in shape. The stelae is devided into three section by two horizontal lines.

The first section of the stelae has got the main scene which is depicting the deceased and his spouse before on offering table. The lower section has got the depiction of his family. And the upper semicircular section has an offering text.

The upper section has three horizontal lines of text. The first line could be read from the middle of it and going in both directions. 
From the left side the text could be read as follows:

xA kAw Apdw Ss

$$
\int_{d} 8 \gamma
$$

One thousand of oxen, birds and linen

From the right side the text could be read as follows:

\section{xA t Hnkt (n) kAd 0 亿}

One thousand of loaves of bread and jars of beer. The second and third lines have got the offerings text formula addressed to Osiris. The text is saying from the left:

\section{Htp di nsw wsir prt xrw n t Hnqt kAw Apdw Ss ${ }^{(7)}$}

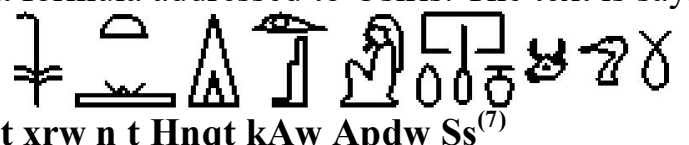

A gift which is given to Osiris by the king, going out of voice, it is composed of loaves of bread, beer, oxen, birds and linen.

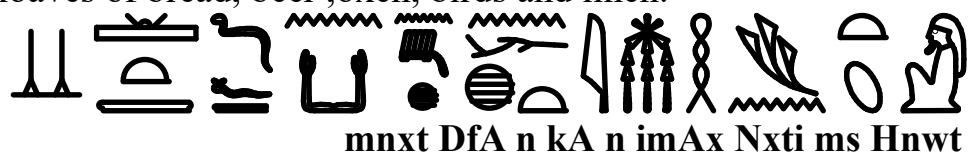

He is also giving cloth and food offerings for the soul of the venerated "nxty ", born of "Hnwt".

In the middle section of the stelae there is the main scene. To the left side of it the deceased and his spouse are both seated on a chair whose legs are resembling the lion pairs and it has a short back. The deceased is wearing a short hair wig, covering the ears, he is putting a kind of collars called "osekht" wsxt" and he is wearing a short kilt. He is putting his left hand on the chest, meanwhile his right hand is outstretched on the thigh towards the direction of his knee.

-The text which is above this scene is saying

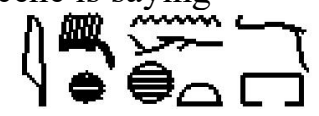

$\operatorname{imAx}$ Nxt imy $-\mathrm{r}$ pr

The venerable, the supervisor of the house "nxt".

His spouse is depicted following her husband and embracing him. The text which is seen above her is saying:

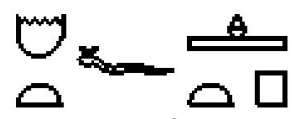

\section{Hmt.f Htp}

His wife Htp

The deceased and his spouse are preceded by an offerings table in the middle of the scene. It is resting on two legs. on the top of the table there are twelve ditch reeds, each six of them are opposite to the others, and they are surmounted by different types of food such as: lettuce, loaves of bread, oxen heads, a steak of meat and a thigh of an ox.

Below the offerings table - to the right side- a ewer could be seen. That ewer is probably containing the water which is used to wash the hands after eating. Below the offerings table to the very left, there is a phrase saying: 
dbHt -Htp which means "stuff concerning the offerings".

The grandson of the deceased is depicted to the very right side of the offerings table as the text is telling :

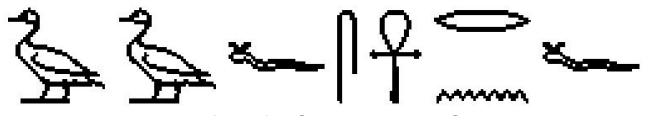

sA sA.f sanx rn.f

The son of his son " sanx rn.f" whose name is alive .

Here the grandson is depicted standing up in front of the offerings table. His right leg is going forward, his left hand is resting aside. Meanwhile his right hand is outstretched towards the offerings table. He is wearing a short hair wig covering the ears and he is putting a kind of a broad collar called "Osekht wsxt". He is wearing a lion cloth whose front is going off set. The text preceding him is saying:

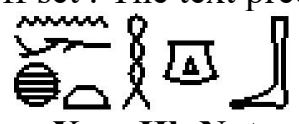

The reciting priest "Nxt".

$$
\text { Xry -Hb Nxt }
$$

It is noticed here that he is not wearing the panther skin which is a characteristic dress of the high priest.

In the third section of the stelae, the family of the deceased "nxt" is lined up as follows: two of his sons his sister and his brother.

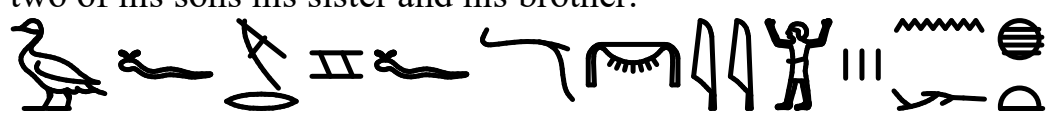

sA.f mr.f imy-r nby nxt

His son, his beloved, the supervisor of the gold smiths nxt .

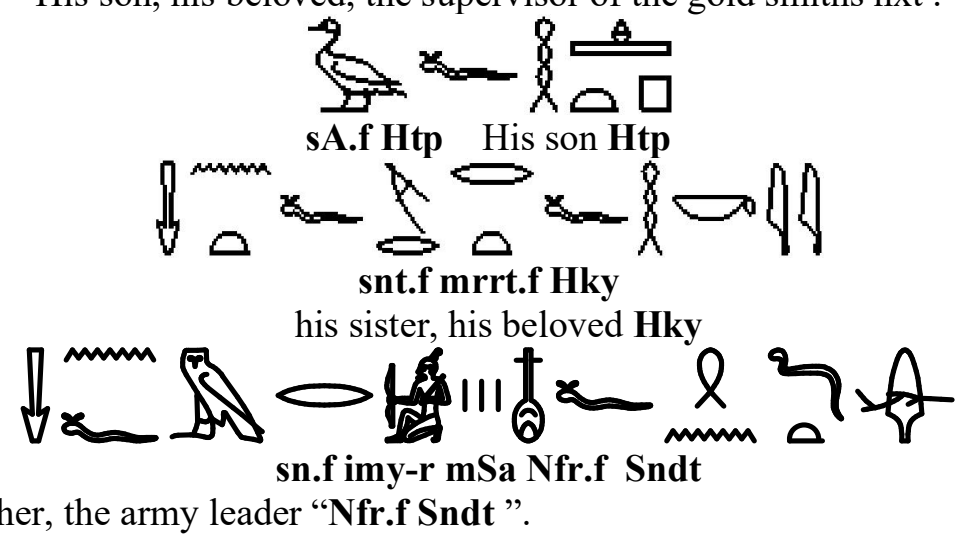

The text is describing the brother as follows: The acacia tree is beautiful.

It is noticed that one of the sons was named after the deceased, and the other son was named after the deceased's spouse.

An analytical study comparing the artistic features in the two stelae:

\section{I-The shape of the stelae:}

The stela of'irr " had a wide semicircular top ${ }^{(8)}$ meanwhile the top of the stela of " nxt " was about to take a pyramidal shape.

Both stelae were divided into three sections by two lines, and that was from the end 
of the eleventh dynasty.

The upper part of both stela had a round depression which had either the offerings text( as it was seen in Nakht's stela) or the titles venerating the deceased( as it was seen in Irr's stela).

The middle parts in both stela were considered- by the ancient Egyptian artisan- the core of earth which could house the deceased. So the deceased was represented seated and followed by his spouse. The middle section of the stela had depictions of different types of offerings to assure the eternal nutriment which was needed by the deceased in the netherworld.

The members of the family were depicted in the lower section of both stela.

These artistic elements were known and popular during the middle kingdom up to the second intermediate period.

However, it was a different case in the old kingdom and the new kingdom. During the old kingdom most of the space in the stela was given to the ritual text and the offerings list. During the new kingdom, the upper recess and the middle section (where the main scene was) were considered to be one unit. Meanwhile, the lower section of it had the offerings text formula, added to it chapters of the book of the dead specially the $30^{\text {th }}$ chapter which was inscribed on the scarabs. During the late period there was a line separating the upper part from the middle section, but still the lower section was kept for the text.

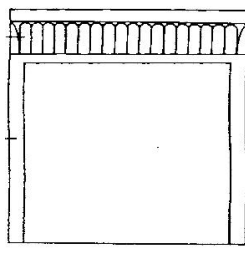

$\operatorname{stela}(a)$

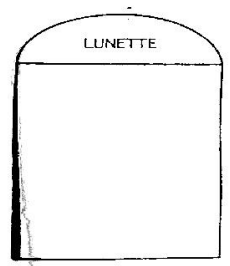

stela (b)
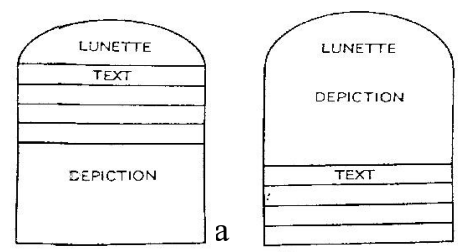

la

la

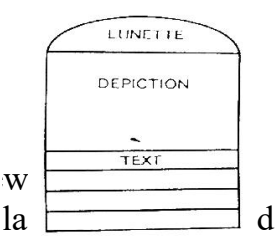

stela

\section{II- The materials of the slela:}

Both stela were made of limestone, and that was very popular tradition from the old kingdom onto the second intermediate period. But in the New kingdom the stela were made of wood or gilded wood.

\section{III- Textual notes:}

The formula of the offering text ${ }^{(9)}$ :

\section{Htp di nsw wsir prt - xrw (n) t Hnkt kAw Apdw}

The gift given by the king.

The formula of the offerings text appeared on Nakht's stelae and it was addressed to the double $(\mathrm{ka})$ of the venerable deceased.

The "ka" is the efficient constituents of the human life. And the ancient Egyptian believed that the existence of the "ka" and joining the body of the deceased are associated with giving the offerings, and this text formula was called " $\mathbf{n} \mathbf{k A} \mathbf{n}$ "

(10)

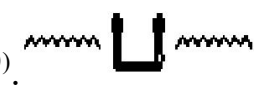

That text formula was consecrated to Osiris lord of Abydos, the official deity from the end of the eleventh dynasty and the beginning of the twelfth dynasty, since 
Osiris was considered the Honor who gives the offerings to the deceased to look after him in the netherworld ${ }^{(\mathbf{1 1})}$.

This text formula is composed of the opening phrase, the name of the god and the prayer of offering. It is dating back to between the reign of the king Pepi $1^{\text {st }}$ and the first intermediate period.

It was traditionally written this way in the eleventh and the twelfth dynasties. Until the second intermediate period and in the new kingdom, it was written as follows:

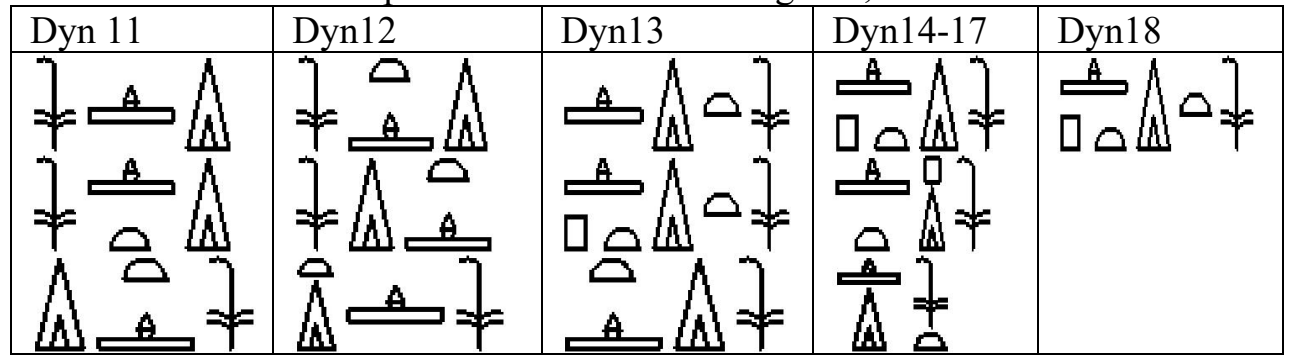

In Nakth's stela, the name of the god Osiris appeared clearly in the text formula. But in IRR's stela it was substituted by the title "the great god, lord of Abydos". And it did not appear in the texts of the old kingdom.

The name of the god Osiris was accompanied by the determinative of the seated god. And that was continuity of the different ways of spelling the god's name, as it

was seen on the stela dating back to the first intermediate period $\int$.But during the reign of the king Sesostris the first and Amnemhat $3^{\text {rd }}$, the determinative of the god was eliminated. The offering prayer "Prt-xrw" was composed of two things:

The first thing is unifying the sign which is representing the house $\square$ with the sign which is representing the oar. The second thing is the cone shape going with the beer jar .

In the old kingdom during the reign of the king Pepi $1^{\text {st }}$ and the first intermediate period, the determinative of the bread loaves appeared going with the adding of a

preposition $^{\text {mmm }}$ on so many stelae.

It was noticed that the grammatical structure of the text formula was different during the middle kingdom.

For instance, the invocation "prt-xrw" (which means prayer) appeared in the $11^{\text {th }}$ dynasty, but in the $12^{\text {th }}$ dynasty this invocation "prt-xrw" was preceded by the phrase "di.f" which means "may give"(12).

\section{IV -The style of inscription:}

In both stelae the inscriptions were engraved on the stone. In the religious texts, inscriptions were going from right to left, but the inscriptions of the names were going from top to bottom.

The inscriptions on irr stelae were clear and in good condition compared with those 
of nxt stelae.

The spelling in Nakht's stelae was detailed which was a popular style in the old kingdom. But, in the stelae dating back to the middle kingdom the signs were smaller in size. Besides, the inscription in the stelaes of the middle kingdom were much less and were not written in a square frame. Moreover, in the middle kingdom's stelaes, the offerings text formula contained the names and titles of the deceased.

In the $13^{\text {th }}$ dynasty, the inscriptions were written with short or brief signs inside vertical columns. In the new kingdom, some letters and some determinatives were written in a kind of fast font. Moreover, the artisans started using abbreviations for

some letters. For instance, the letter

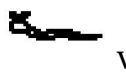
was written in a specific way in Nakth's stelae which was different from that written in IRR's stela, and the size of the letters in Nakth's stela is bigger than that in IRR's stelae.

\section{V-The Titles:}

\section{- imAxy:}

In the stelae of Nakht, the title which was written as follows: $\operatorname{imAx}$ or $\operatorname{imAxy}$ (meaning the venerable) was a secular title during the Eleventh dynasty. In the 12 the dynasty specially during the reign of the king Amnemhat $2^{\text {nd }}$, the title "imAx" was preceded by the word "n kA n" to give the meaning of the following phrase : "the soul of the venerable to the king".

In the reign of the king seonowsert $3^{\text {rd }}$, the word "imAx" was substituted by the

word which shortly became a religious title meaning "the venerated by the gods".

- Nb Abdw

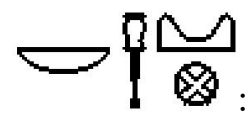
" the lord of Abydos". This title was popular in the era between the first intermediate period and the 12 the dynasty.

Spelling the title by adding the letter 2 was most popular at that period.

The god Osiris was associated with Abydos since it was the location of his tomb. So, Abydos became a sacred spot and a place to pilgrimage to, especially in the middle kingdom ${ }^{(13)}$.

$$
\text { iry -pat : }:^{(14)}
$$

It is one of the honorary titles and it was seen on the stelae of irr.

Mr Nabil Marawan did study this title thoroughly in the context of his study about the titles given to the queen Nefertari wife of Ramses $2^{\text {nd(15) }}$.

Mr. Marawan Said (transcribing from Gardiner) ${ }^{(16)}$ that the word "iry " is considered a part of the preposition "r" which means "belongs to". And so, that title means: "that who belongs to that class of people "pat"(17).

Mr. Erman believes that the word "pat" refers to the original natives of ancient Egypt. Meanwhile, Mr Pirenne thinks that they were nobles or the elite class of ancient Egypt. But, Mr. Abdel Aziz Saleh believes that the word "pat" is an epithet describing the high class people of the society to be distinguished from the 
commoners $^{(18)}$.

Mr. Saleh also believes that the word "pat" is closer to the meaning of the word elite or people of distinction. It is true that this title was given to officials and governors of the provinces, but it was nothing more than an honor granted to them.

This title was held by 43 ministers of the capital city, most of them are going back to the $12^{\text {th }}$ dynasty, and some of them are going back to the $11^{\text {th }}$ and 13 the dynasties.

\section{- HAty-a:}

This title appeared on the stelae of irr.Most of the titleholders were of the rank "HAty-a" during the middle kingdom, on to the new kingdom ${ }^{(19)}$.

- Xry-Hp ${ }^{(20)}$ :

This title means "the reciting priest carrying the book of the rituals". It appeared on the stelae of Nakht and it was one of the popular religious titles especially among the viziers. It was also held by high officials and it appeared just once in the texts belonging to the vizier "Monthotep" during the reign of the king Senowsert 1 st

- imy-r pr:

This title means the house supervisor and it was on the stelae of Nakht. It was one of the titles related to the royal palace. Some of the titleholders were governors of the south during the middle kingdom, one of them was named "Kheber ka Ra Iny".

\section{- imy-r mSa :}

It was seen on the stelae of Nakht. It was translated as "the expedition leader". Mr. Schulman interpreted it as "military officer" and he believes that it was not a distinguished rank. But the titleholder was a kind of military leader who was seen in the representations of Habu temple receiving orders from the "general commander" imy-r mSa .

It is thought that this title was higher than the rank of the recruited soldiers, and it was a kind of honor and it was higher than the rank of imy-r pr.During the old kingdom this title was equal in rank $^{(21)}$ with the tile "imy-r mSa " which was not used yet. The titleholders were using the mines of minerals, supervising the desert areas and defending the borders. This trend was assured in the middle kingdom, since the governors of the provinces were considered the military units who were used in the provinces to protect the establishments and to carry out different missions $^{(22)}$.

- rx nsw :

It is translated into "the one who is known to the king". It was seen on the stelae of irr and it was indicating how close to the king the titleholder was ${ }^{(23)}$.

- sA.f mr.f ${ }^{(24)}$ :It means "His son, his beloved", the title was seen on both stelaes and it is dating back to the old kingdom, and it was used over the different eras ${ }^{(25)}$.

The stelae of irr:

The artisan followed the funeral style in making the stelae, showing the deceased sitting down and having a beard -imitating the figure of the king- with the eyes full of adulation.

The curly hair wig has got prominent angles with clear tops and showing the ears. The chest muscles are connected to the rest of the torso in a wavy way. The belly button is seen on the abdomen which is characteristic feature of art in the reign of Senowsert $2^{\text {nd }}$, and the later eras ${ }^{(26)}$. So the representation of the deceased this way is 
showing his social position which was adapted from the kings of the twelfth dynasty.

His sons are wearing the kilt which is above the knee and putting another transparent one above it, which was ornamented on the top and some pleats were added to the lower part of it, and some fringes are hanging down from the middle of the kilt, and putting curly hair wigs and outstretching their hands aside.

\section{-The stelae of Naktht:}

Size wise, Nakht was represented as big as his wife, but smaller than the depiction of IRR on his stlae. Nakht was represented sitting down -like IRR- but folds of his arm were seen (those folds were also seen in the monuments of "kaweet and Asheet). Nakht's arm is not outstretched like that of IRR.

His sons are wearing Lion cloth with the off-set front which is inspired from the old kingdom specially the third dynasty, and it was used the tail in the $11^{\text {th }}$ dynasty. Moreover, they are wearing broad collars and putting straight hair wigs. One of the sons is raising the left hand and putting the other hand aside, and this is the perspective style which was borrowed from the art of the old kingdom.

\section{VI-The offerings table:}

In both stelae the list of the rituals concerning giving the offerings were brief ${ }^{(27)}$. That kind of rituals lists -which was represented on the stelae dating back the old kingdom- was arranged in rectangular boxes or in square frames above the deceased. But here in the stelae of the middle kingdom there was a symbolic substitution of those rectangular lists.

In the stelae of IRR: the offerings table is represented in a big scale matching the position of the owner of the tomb. The table is supported by a middle short stand which is a little bit broad.

On the offerings table there are eight loaves of bread (each four of them are opposite to the others) which are put vertically and they resemble the ditch reeds. Above the loaves there is the brief offerings list which is known as "the list of the thousands" (which is also seen in the offerings text formula in the stelae of Nakht). Below the offerings table to the very right side there is a representation of a ewer. Below the offerings table to the very left side there is the phrase "dbHt-Htp", which means "the materials of the offerings".

In the stelae of Nakht, the offerings table is represented in a small size matching the position of the deceased. It is surmounted by twelve loaves of bread in two rows, above which some of the offering materials were depicted in a materialistic not a symbolic way.

Moreover, it was the same kind of representation underneath the offering table- just like those on the stelae of IRR- with one difference which is the rectangular shape of the ewer. That ewer was represented on some stelae dating back to the end of the $11^{\text {th }}$ dynasty (an example: a scene from the tomb of Baket) ${ }^{(28)}$.

In the stelae of IRR: The right side of the offerings table has got representations of offering materials such as: onion, fish, loaves of bread and incense. Underneath the table there is the offerings stand inside which there is the ewer and carrying the pots and jars which were used in performing the different rituals such as the ritual known as: qbH-nmst-Hs

In the stelae of Nakht: There was not the same representation to the right side of 
the offerings table. But it was the representation of the grandson of the deceased who was occupying the job of : "the reciting priest" (as it was mentioned in the text).

This scene was represented on some stelae of tombs dating back to the end of the $11^{\text {th }}$ dynasty. For instance, the tomb of Akh Hotep 2nd who was serving during the reign of Senowsert1 ${ }^{\text {st(29). }}$.

It is noticed that in the old kingdom and the first intermediate period that the topic of the scene in that part of the stelae was different. Namely, that part of the stelae in the old kingdom and the end of the $11^{\text {th }}$ dynasty had the representation of the offerings bearers. For instance, the tomb of "Baket" in Bani Hassan, the tomb of "Akh Hotep $2^{\text {nd }}$ " in "Meer" in middle Egypt and the Tomb of "Amnemhat" in Bani Hasan ${ }^{(30)}$.

The artisan was writing a name with different ways of spelling, and that meant that he was giving an epithet to the titleholder; like what was written on the stelae of Nakht who was called sometimes Nakhty. Another example is the name "Amnemhat" which was written "Aminy"(31).

Most of the researchers have agreed that the reeds of plants on it representing the loaves of bread which are considered the extension of the fields flanking the Nile river on the east and west sides. Those vast lands are encompassing different kinds of birds, fish, cattle barns, storage places and everything. Moreover, the deceased is considered incarnation of Horus the lord of that cultivated land and fields, and he is the one increasing their fertility and bringing fruitage out of them.

\section{Conclusion:}

The character and technique of two stelae suggests that the two stelae date back to the end of the $11^{\text {th }}$ dynasty and the beginning of the $12^{\text {th }}$ dynasty, for the following reasons.

- In the stelae of IRR, it was mentioned that one of his children was called "Senowsert ", that was not an evidence that Senowsert 1 st ascended the throne, but it is an indication that he was in charge of ruling, and beside him his wife's name " int.f" was the name of one of the kings of the second intermediate period.

- The continuity of writing the invocation formula "prt.xrw" without being preceded by the phrase "di.f" (keeping in mind the prayer phrase with di.f) was traditionally used in the middle of the $12^{\text {th }}$ dynasty.

- The title "nTr-aA" was rarely used after the name of Osiris in the middle of the $12^{\text {th }}$ dynasty.

- The title "Xry - Hb" appeared just once in the tomb of Nakht among the inscription of the vizier Monthotep during the reign of Senowsert $1^{\text {st }}$.

- The depiction of the offerings stand on the stelae of IRR is dating back to the end of the $11^{\text {th }}$ dynasty.

- Writing the phrase "n kA n" preceding the word "imAx" (meaning venerable) on the stelae of Nakht is dating back to the reign of "Amnemhat $2^{\text {nd". }}$

- On the stelae of IRR, the artisan followed the style of the north Memphite school of art which was known during the reign of Senowsert $1^{\text {st }}$ and Amnemhat $1^{\text {st }}$. That style of art was showing the real size of the deceased which is representing his social position (as comprehended from his titles).

The name of both irr and nxt are mentioned in two stelea dating back to the 12 
Dynasty. the first is a limestone stelea with a semicircular top belonging to a person

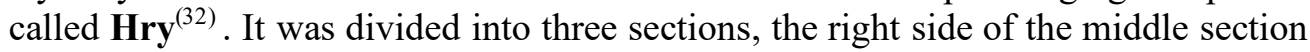
has got the names of five people, the first of whom was known as irr who was preceded by four ladies representing his daughters, (they are Hebi-Ibet- satet and Hathor the acquitted), and the other is an offering stelae discovered in a good shape and well preserved in the northern cemetery of Abydos. It belongs to a person called "mmm engraved and saying: Sิ Nakhty, son of Nakht.

Family of IRR

$\left.\begin{array}{|l|l|l|l|l|l|}\hline \begin{array}{l}\text { the } \\ \text { owner's } \\ \text { stelae }\end{array} & \text { Titles } & \text { wife } & \text { Mother } & \text { children } & \begin{array}{l}\text { The principal } \\ \text { mother of the } \\ \text { children }\end{array} \\ \hline M C & \begin{array}{l}\text { imAx } \\ \text { iry-pat } \\ \text { HAty-a } \\ \text { dAir srf }\end{array}\end{array}\right)$

2- Family of Nakht

\begin{tabular}{|c|c|c|c|c|c|c|c|}
\hline $\begin{array}{c}\text { the } \\
\text { owner's } \\
\text { stelae }\end{array}$ & titles & Wife & mother & children & grandson & sister & brother \\
\hline$\stackrel{\min }{2}$ & $\operatorname{im} A x$ & $\begin{array}{l}0 \\
\end{array}$ & & 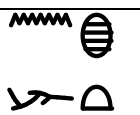 & $1 \mathbb{1}_{\mathrm{\alpha mm}}$ & & \\
\hline
\end{tabular}

\section{Abbreviation list}

AEO: Ancient Egyptian onomastica (London).

JEA : Journal of Egyptian Archaeology, (London)

MÄS: Munchner ägyptologische studien, (Berlin).

URK Urkunden des Alten Reichs, (Leipzig).

WB: Wörterbuch der ägyptischen sperache, 6 vols, (Leipzig Berlin).

\section{Bibliography}

$$
\begin{aligned}
& \text { 1 - عائشة محمود محمد عبد العال، لوحات افراد الدولة الوسطى ، رسالة ماجستير (غير منشورة)،القاهرة، } 1990 \text { ( } 190
\end{aligned}
$$

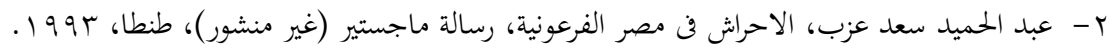

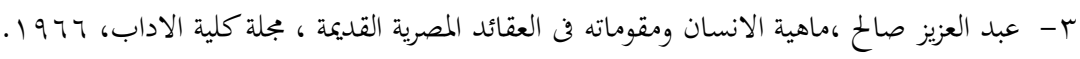

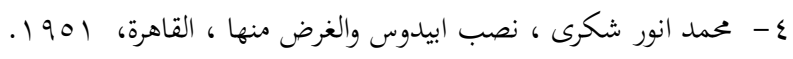

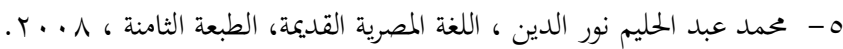




$$
\begin{aligned}
& \text { צ- نبيل مروان، الملكة نفرتارى زوجة الملك رمسيس الثانى واثارها من خلال القرن الثالث عشر قبل الميلاد، رسالة ماجستير }
\end{aligned}
$$

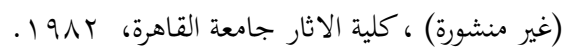

$$
\begin{aligned}
& \text { V- وزير وزير عبد الوهاب ،الازدواجية في الالقاب الادارية فن مصر حتى فهاية الدولة الحديثة، رسالة ماجستير (غير منشورة }
\end{aligned}
$$

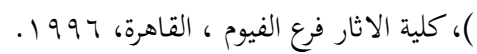

8- Barta, W., "Die altägyptische Äpferliste von der fruhzeit bis zur Griechiseche aromischen Epoche, Munchen", M̈̈S 3, 1963.

9- Blackman, M.A., The Rock Tombs of Meir II; The Tomb chapel of Senbi's son ukhhotp. (B.No.2), London, ASE 23, 1915

10- - Aylward, M., "The Nagent and Haggard Collections of the Egyptian Antiquities", JEA IV, London, 1917.

11. Bonnet, C. J., "Growth of the htp-di-nsw formula in the Middle Kingdom", JEA 27, London, 1941

12- Catalogue General des antiquités Egyptiennes No. 23001-2325, Table D'offrandes, le Caire, 1909.

13- Fischer, H.G., Egyptian Titles, of the Middle kingdom, New York, 1997, 1997.

14- Gardiner, A.H., "The Eloquent peasant", JEA 9, London, 1923.

15- _ , "Egyptian Grammar", Oxford, 1973.

16- Hassan, S., Excavation at Giza, VI, 1934-1935, part II: the offering list in the old kingdom, Cairo, 1948.

17- Jones, D., An index of ancient Egyptian Titles, Epithets and phrases of the old kingdom, Vol II, 2000 .

18- Kamal Bey, A., Catalogue General des Antiquities Egyptienes du Musee du Caire, no : 23001-23256, le Caire, 1909.

19- Simpson, W. K., The Terrace of the Great God at Abydos: The offering chapter of Dynasties 12 and 13, philadlphia, 1974 .

20- Murray, M.A., Saqqarah Mastabas, part I, London, 1989.

21- Newberry, P. E., Beni.Hasan I, London, 1893.

22-__, Beni- Hasan II, London, ASE 2, 1893

23- Pirenne, J., Hostorie des Institution et du droit prive de Anciene Egypt III, Bruxelles, 1932-1935

24- Quirke, S., Titles and Breaux of Egypt 1850-1700 B.c, 2004.

25- Ranke, H., Die äegyptischen personalnamen, Band, 1, 1936.

26- Schulman, C.R., "Military Ranke, Title and organization in the Egyption New kingdom", MÄS 6, Berlin, 1964 .

27- Smither, P., "The writing of Htp.di-nsw in the Middle and New Kingdom", JEA 25, London, 1939. 
'( ( ) أتقدم بالشكر إلى د/ لطفي عبد الحميد، وكيل المتحف المصري لشئون الآثار، والأستاذة/ مروة عبد الرازق محمود،

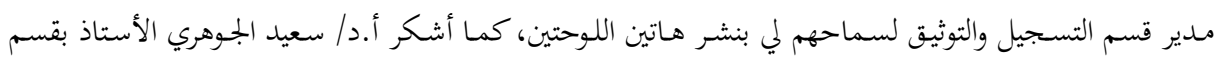

اللغة الإنجليزية بكلية آداب طنطا، ذلك لتفضله بمراجعة اللغة الإنجليزية، كنسخة أولية من المقالة.

(2) wb II, 461 (12).

( 3) Gardiner, A., "The Eloquent peasant", JEA 9, London, 1923, p.21.

(4) The ancient Egyptian believed that sitting down was merely representing a middle phase in between death and resurrection. Sitting down was practicing the different activities of life with all its movements. In this phase he is ready to stand up, and this is considered resurrection and immortal life. see.

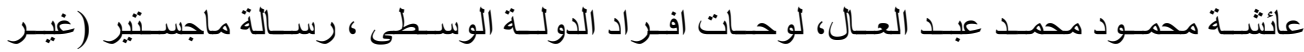

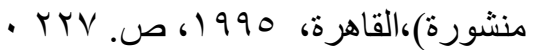

(5) A fabric of linen representing a natron pacbet is ramging from a mast. The natron salt had a religious meaning to the ancient Egyptian since it was used in de hydrating the corpse during the mummification process, and it was called "nTry" which means the sacred. In the late period, the natron salt was given as offering and it was associated with resurrection see.

LÄ IV (1982), colo.358f.

(6) Mny was derived from the Names Mn or Imn or Mny, Which was Comoner name in the Early Dynasty.

( 7) Kamal Bey, A., Catalogue General des antiquités Egyptiennes No. 23001-2325, Table D'offrandes, le Caire, 1909, p. 22f.

( 8 ) There are different opinions about the round shape of the upper part of the stela: It is resembling the designs of the rock cut tombs which had vaulted chambers and galleries inside, the stela was considered a representation of the whole tomb not only the entrance of the tomb, the stela is an imitation of Anubis chapel where the "ceremony of the opening of the mouth" of the deceased was performed, the stela is resembling the sky arch which is representing the goddess of the sky "Nwt" who was confronted by the god "Geb"( god of earth), represented by the ground of the stela.

Meanwhile, the flanks of the stela were representing the god "Shou" who is keeping "Nwt" and "Geb" apart. And so, from this concept- the deceased is going to gain the eternal life and resurrection just like the god Osiris. See:

Zayed, A.A., "painted wooden stela in the Cairo Museum", RDE 20, 1968, p. 149ff;

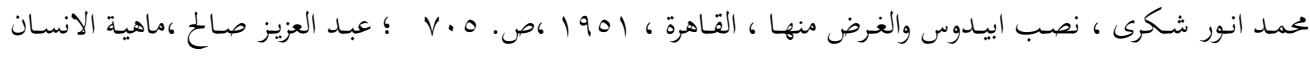

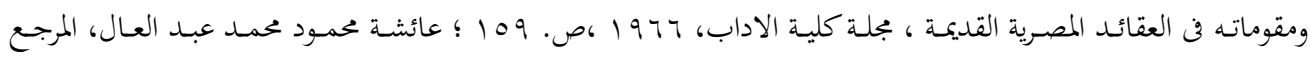

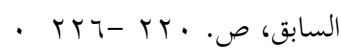

( 9) Bonnet, C. J.", Growth of the http-di-nsw formula in the Middle Kingdom", JEA 27, London, 1941, p.77-8;

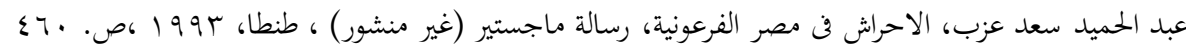

( 10) Smither, P., "The writing of Htp.di-nsw in the Middle and New Kingdoms", JEA 25, London, 1939, pp.-34-7; 
Gardiner, A.H., Egyptian Grammar, oxford, 1973, p. 170-2.

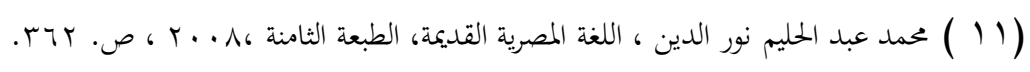

( 12) Smither, P., op.cit., p.-34-7; Gardiner, A., op.cit., pp. 170-2.

(13) Simpson, W.K., The Terrace of the Great God at Abydos: The offering chapter of Dynasties 12 and 13, philadlphia, 1974, pp. 1-16.

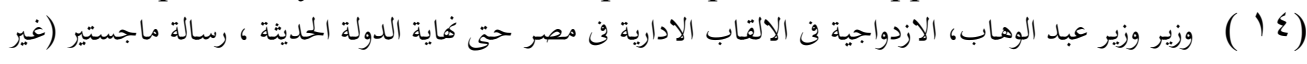

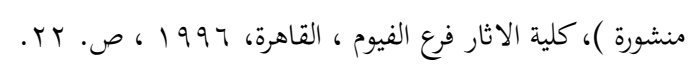

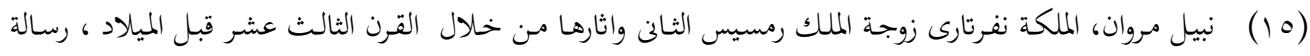

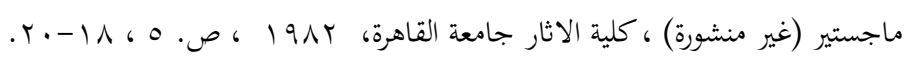

( 16) Gardiner, A. H., Ancient Egyptian onomastica, Vol III, London, 1949 p. 108, 109.

(17) $\mathrm{Wb} \mathrm{I}, 503$.

( 18) Pirenne, J., Hostorie des Institution et du droit prive de Anciene Egypt, III, Bruxelles, 1932-1935, p. 430.

(20) Wb III, 395 (4-10); Urk I (1903), 189 (10); Jones, D., An index of ancient Egyptian titles, Epithets and phrases of the old kingdom, Vol II, 2000, p, 781.

(21) Schulman, A.R., "Military Ranke, Title and organization in the Egyptian New kingdom", M̈̈S 6, Berlin, 1964,p. 42f ; Quirke, S., Titles and breaux of Egypt 1850-1700 B.c, 2004, p.97.

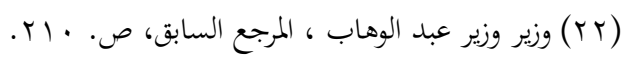

( 23) Quirke, S., op.cit., p. 60.

(24) Fischer, H.G., Egyptian Titles, of the Middle Kingdom, New York, 1997, p. 24.

(25) Murray, M.A., Saqqarah Mastabas, part I, London, 1989, pl. 3.

(26) Fischer, H.G., op.cit., p. 24.

(27) Barta, W., "Diealtagyptische Öpferliste von der fruhzeit bis zur Griechiseche aromischen Epoche, Munchen". M̈̈S 3, 1963, p. 47-50; Hassan, S., Excavation at Giza, VI, 1934-1935, part II: the offering list in the old kingdom, Cairo, 1948, p. 164-6.

(28) Newberry, P.E., Beni- Hasan II, London, ASE2, 1893, pp. 32- 6, pl. 30.

(29) Blackman, M.A., The Rock Tombs of Meir II, The Tomb chapel of Senbi's son ukhhotp. (B.No.2), London, ASE 23, 1915, pl. 10.

(30) Newberry, P. E., Beni. Hasan I, London, 1893, p.33, pl. 17.

(31) Ranke, H., Die Äegyptischen personalnamen, vol 1, 1935, p. 212 (1).

(32) Blackmann, M.A., \& Aylward, M., "The Nagent and Haggard Collections of the Egyptian Antiquities", JEA IV, London, 1917, pp.39-40, pl.10.

(33) Kamal, A., Catalogue General des Antiquities Egyptienes du Musee du Caire, no : 23001-23256, le Caire, 1909, p. 22-3, no 23027. 